\title{
EFFECT OF POTTING MIXTURE ON GROWTH AND YIELD OF CHILLI VARIETIES (CAPSICUM SPP) AND MICROBIAL ACTIVITY
}

\author{
DahanayakeN, Madurangi SAP, RanawakeAL \\ Department of Agricultural Biology, Faculty of Agriculture, University of Ruhuna, Sri Lanka
}

Accepted: 20 September 2011

\begin{abstract}
The study was carried out as pot experiments using a Green Chilli variety, MI 2, and a Curry Chilli variety, Hungarian Yellow Wax (HYW) at the research field, Faculty of Agriculture, University of Ruhuna. The basal soil mixture was prepared using coir dust, sand, soil and cow-dong (1:1:1 control). Four different potting mixtures were prepared by adding tea waste, compost and inorganic fertilizer. The experiment was carried out according to complete randomized block design with four replicates at the rate of 8 plants per replicate. Plant height $(\mathrm{cm})$, number of pods/plant, weight of pods per plant $(\mathrm{g})$, pod length $(\mathrm{cm})$ and pod appearance were recorded. Carbon-dioxide $\left(\mathrm{CO}_{2}\right)$ evolution method was applied to observe soil microbial activity in different soil mixtures.

Potting mixture combined with tea waste showed significantly highest plant height for both chilli varieties HYW $(42 \mathrm{~cm})$ and MI-2 $(55 \mathrm{~cm})$ while minimum plant growth in both varieties was recorded in control $(\mathbf{P}<0.05)$ basal soil mixture. The highest no of pods $(35.5 /$ plant) was recorded in MI-2 grown under inorganic mixture, while the lowest $(10.5$ / plant) was recorded in the control treatment. There was no considerable difference in pod production in HYW for tested potting mixtures. In addition, the highest mean microbial activity was observed in potting mixture filled with tea waste whereas the lowest microbial activity was observed in potting mixture with inorganic fertilizer. However, there was no any variation in pod length and pod appearance of both varieties grown under different soil mixtures.
\end{abstract}

Key words: Capsicum annum,, Microbial activity

\section{INTRODUCTION}

Chilli (Capsicum) is one of the economically important vegetable crops cultivated in Sri Lanka. Both dry and fresh pods of Chilli are commonly used in cooking recipes to achieve the taste of daily food with high palatability and nutritious values. Apart from these, Chilli pods could be used in many industrial products, e.g., animal rations, insecticides (Siriborirak 1996). Presently Chilli production is mostly depend on the inorganic fertilizer, but due to the problems associated with any inorganic fertilizer Chilli production using organic fertilizer is also timely needed.

Pot technique is an open system of vegetable cultivation. The diversification of potting techniques makes agriculture more profitable through efficient land use and maximum utilization of natural resources. The constitution of the potting mixture directly effects on the final yield of the crop and the several factors must be considered when select the most suitable potting mixture. The availability of nutrients in the potting mixture directly effect on the final economical yield. Cattle manure, paddy husk ash, coir dust, sand or gravel, peat, vermiculite, perlite, sawdust are normally used materials for preparation of soil mixtures. Among these, cattle

*Corresponding author : nilanthi@agbio.ruh.ac.lk manure, coir dust and paddy husk ash are locally available user friendly cheaper organic manures and those materials contain certain amount of major nutrients $(\mathrm{N}, \mathrm{P}$ and $\mathrm{K})$.

Micro-organisms enhance soil fertility in organic fertilized soils (Panyakul 2004). Microbial activity in soil is enhanced or suppressed by the ingredients of the soils. As an example presence of lignin and hemi-cellulose decreases microbial activity while presence of phenolic glycosides enhances microbial activity (Van Sumere 1989). This is due to the $\mathrm{pH}$ and EC values of soils due to the secondary products of degradation of these materials (Hoitinket al. 1997). Other than these soil temperature, water retention ability of the soil and soil texture directly effect on microbial activity. However, the availability of nutrients in the root rhizosphere of the crop is determined by the type of soil mixture.

Therefore the objectives of this study were to evaluate the growth and yield performances of Chilli varieties in different soil mixtures and to compare the degree of microbial activity in Chilli and HYW grown in different soil mixtures.

\section{METHODOLOGY}

The experiment was carried out at the research field, Faculty of Agriculture, University of Ruhuna. 
Two Chilli varieties MI 2 and Hungarian Yellow Wax (HYW) were used to investigate the effect of soil mixture on the plant height $(\mathrm{cm})$, mean number and weight of pods $(\mathrm{g})$ per plant, pod length $(\mathrm{cm})$, pod appearance and microbial activity of the soil separately. Four soil mixtures; tea waste, compost and inorganic fertilizer were used for the experiment and the result was compared with control (Table 1). Basal dressing: Applied and incorporated into the soil before sowing - Urea 35, Triple super phosphate 100, Murate of potash $75 \mathrm{~kg} / \mathrm{ha}$. Top dressing: Urea $30 \mathrm{~kg} / \mathrm{ha}$ Applied at flowering.

\section{Determination of soil microbial activity}

Soil microbial activity was measured according to the $\mathrm{CO}_{2}$ evolution method. Soil sample $(10 \mathrm{~g})$ from the Chilli cultivated pot was taken in to a jam bottle and mixed with $3.5 \mathrm{ml}$ distilled water. The controller set was filled with $3.5 \mathrm{ml}$ of distilled water. Ignition tube was taken and filled with $3 \mathrm{ml}$ of $2 \mathrm{~N}-$ $\mathrm{NaOH}$ and then placed on the jam bottle so that the emitted $\mathrm{CO}_{2}$ from the soil will be absorbed in to the $\mathrm{NaOH}$ solution. Soil samples were kept in dark room for one week. Then contents in ignition tubes were washed in to $250 \mathrm{ml}$ conical flasks separately and mixed with $7.5 \mathrm{ml}$ of $2 \mathrm{~N} \mathrm{BaCl} 2$. Few drops of phenolphthalein were added and mixtures were titrated by $0.5 \mathrm{~N}-\mathrm{HCl}$. Burette reading was taken at the point of which burette color changes from pink to colorless. Experiment was carried out according to complete randomized block design with four replicates and 8 plants per replicate.

Table 1: Soil mixtures and ratios applied for the test Components of $\mathrm{T}_{1}$ (Tea $\mathrm{T}_{2}$ Com- $\mathrm{T}_{3}$ (Inorganic $\mathrm{T}_{4}$ the potting mix-waste) post) fertilizer) (Control) ture

$\begin{array}{lllll}\text { Tea waste } & 5 \text { parts } & - & - & - \\ \text { Coir dust } & 5 \text { parts } & 5 \text { parts } & 5 \text { parts } & 5 \text { parts } \\ \text { Sand } & 5 \text { parts } & 5 \text { parts } & 5 \text { parts } & 5 \text { parts } \\ \text { Top soil } & 5 \text { parts } & 5 \text { parts } & 5 \text { parts } & 5 \text { parts } \\ \text { Cow dung } & 5 \text { parts } & 5 \text { parts } & 5 \text { parts } & 5 \text { parts } \\ \text { Compost } & - & 5 \text { parts } & \begin{array}{l}\text { Inorganic } \\ \text { fertilizer }\end{array} & - \\ & & & \text { fertizer }\end{array}$

Randomized Complete Block Design (RCBD)with four replicates was used for the field trial.

\section{RESULTS AND DISCUSSION}

\section{Effect of potting mixture on growth and yield} performances of tested Chilli varieties

Results of the field trial revealed that there was a significant effect of potting mixture on growth and yield performances of Chilli. Potting mixture filled with tea waste showed the significantly highest plant height $(42 \mathrm{~cm})$ in HYW compared to that of other potting mixtures (Table 1). The same highest plant height $(55 \mathrm{~cm})$ was recorded in pot- ting mixtures supplemented with compost and tea waste in HYW. However, plant height of potting mixture supplemented with inorganic fertilizer didn't show a significant difference with control plant height in both varieties (Table 1). Mean plant height of HYW and MI2 at maturity stage $(\mathrm{cm})$ under different potting mixtures was recorded 6 weeks after planting.

Potting mixture significantly affects on final yield (g/plant) of HYW and MI-2 $(\mathrm{P}<0.05)$. The highest no of pods (35.5/ plant) were recorded in MI-2 plants grown in inorganic mixture whereas the lowest pod production was recorded in control treatment. However, there was no any significant difference in number of pods/plant in HYW in tested potting mixtures (Table 1).

Mean pod weight of HYW under different potting mixtures was not significantly different while mean pod weight of MI-2 recorded significantly different pod weights in different soil mixtures (Table 1). The highest mean pod weight (2.37 g) of MI-2 was recorded in control plants but it was not significantly different from the pod weight observed in tea waste and compost (Table 1). This result is with agreement of the findings of other horticultural crops as well (El- Bassiony, 2006; El-Desukietal., 2006; Fawzyetal. 2007). There was no any significant variation in pod length and in pod appearance in both varieties grown in different soil mixtures.

In the Table 01 it shows the average $\mathrm{HCl}$ volumes $(\mathrm{ml})$ required for the titration of soil samples taken from different potting mixtures of two tested varieties (Less volume of $\mathrm{HCl}$ is needed when the microbial activity is higher in the soil sample). There was a significant effect of potting mixture on microbial activity of the soil (Table 01 ). According to the results, the highest mean microbial activity was observed in MI-2 grown potting mixture containing tea waste and control soil mixture grown in HYW. Microbial activity in all the HYW cultivated soils was higher than MI-2 cultivated soils except HYW cultivated soil mixture containing compost. Potting mixture supplemented with inorganic fertilizer showed significantly lowest mean microbial activity in MI-2 grown soils but in HYW grown soils, compost containing soil mixture recorded the lowest microbial activity (Table 1). Furthermore, MI-2 cultivated compost contained soils showed significantly higher microbial activity than that of in HYW cultivated compost containing soil. This is an evidence for the effect of root exudates on microbial activity in soils. This has been described by Paterson et al. 2007 and Barréet al. 2009 where 
they observed that the microbial activity in the soil is differed with the cultivation.

Cattle manure is the most commonly used organic manure in Agriculture. Addition of cattle manure to potting mixture improves the physical properties of soil, microbial activity and nutrient availability especially $\mathrm{N}, \mathrm{P}, \mathrm{K}$ because it contains $0.35 \% \mathrm{~N}, 0.12 \% \mathrm{P} 2 \mathrm{O} 5$ and $0.17 \% \mathrm{~K} 2 \mathrm{O}$ (Tandon, 1999). However, in the present study the highest mean microbial activity was recorded in MI- 2 grown potting mixture contained tea waste and in HYW grown control soil mixture (Table 1). According to the correlation analysis there was no correlation between microbial activity of the soil mixture and final yield of both HYW and MI-2. Significantly highest mean microbial activity was observed in potting mixture filled with tea waste and in control potting mixtures. The highest microbial activity does not mean the highest yield in each case as varietal response is also effect on yield. This has been reported by Gijsmanet al., 1997.

Table 01. Effect of different soil mixtures on the growth of Chilli varieties and their effects on variation of soil microbial activity (measured by the Required $\mathrm{HCl}$ volum in $\mathrm{ml}$ )

Trt Mean Plant Mean Num- Mean Pod Soil MicroHeight $(\mathrm{cm})$ ber of Pods Weight $(\mathrm{g})$ bial Activity

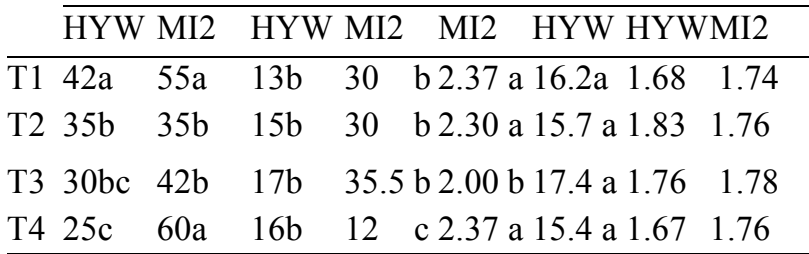

\section{CONCLUSION}

Among tested mixtures, tea waste: sand : coir dust 5:5:5 is the best mixture for the vegetative growth of both HYW and MI-2 varieties but the highest number pod production of both HYW and MI-2 was observed in the potting mixture supplemented with inorganic fertilizer (Coir dust 5: Sand 5; Top soil 5: Cow dung 5).

\section{REFERENCES}

El- Bassiony AM 2006 Effect of potassium fertilization on growth, yield and quality of onion plant. J. Appl. Sci. Res., 2(10): 780-785

El-Desuki MM Abdel-Mouty M Ali AH 2006 Response of onion plants to additional dose of potassium application. J. Appl. Sci. Res., 2 (9): 592-597

Fawzy ZF, El-Nemar MA and Saleh SA 2007 Influence of Levels and Methods of potassium Fertilizer Application on Growthand yield of Eggplant. J. Appl. Sci. Res., 3(1): 42-49

Panyakul W 2004 Sustainable Agriculture: Agricultural Pathways for Future. SaiyaiPandinFoundation,Bangkok, Thailand,pp:335

Siriborirak S 1996 Pharmaceutical Foods. Bangkok, Bangkok Publishing House

Tandon HLS 1999 Organic fertilizer and Biofertilizer. A Techno- Commercial source Book, Fertilizer Development and Consultation Organization, New Delhi.

Van Sumere CF 1989 Methods in Plant Biochemistry, Vol. 1 Plant Phenolics, Dey, P.M. and Harborne, J.B. (Eds.), Academic Press, London, 29

Hoitink HAJ, Stone AG and Han DY1997 Suppression of plant disease by composts. Hortscience 32, 184-187

Barre P and Hallett PD 2009 Rheological stabilization of wet soils by model root and fungal exudates depends on clay mineralogy. European Journal of Soil Science 60, 525-538.

Paterson E, Gebbing T, Abel C, Sim A and Telfer G 2007 Rhizodeposition shapes rhizosphere microbial community structure 